\title{
Self and Peer Assessments in Active Learning Model to Increase Metacognitive Awareness and Cognitive Abilities
}

\section{Yuni Pantiwati}

Faculty of Teacher Training and Education, University of Muhammadiyah Malang, Malang 65144, East Java, Indonesia, yuni_pantiwati@yahoo.co.id

\section{Husamah}

Faculty of Teacher Training and Education, University of Muhammadiyah Malang, Malang 65144, East Java, Indonesia, usya_bio@yahoo.com

Metacognitive awareness constitutes a part of thinking skills to continuously retain and develop. One of efforts to increase metacognitive awareness is conducting training through lecture integrated in active learning. Self and peer-assessments encourage students to be more responsible for their performance improvement and learning. The population comprised students attending Natural Science course in Faculty of Teacher Training and Education, University of Muhammadiyah Malang; while the samples were all members of the population taken by means of saturation sampling technique. The technique of data collection was by means of Schraw and Dennison MAI (Metacognition Awareness Instrument), written test, and document analysis. The result path analysis showed: 1) there are influences of self and peer assessment in active learning towards awareness of Metacognition and cognitive ability; 2) cognitive knowledge, regulation of cognitive, and combined both contributed to its influence on Metacognition awareness; 3) cognitive knowledge, regulation of cognitive, and combined both contributed to its influence on cognitive variables; and 4) metacognitive awareness variables have a direct contribution to cognitive variables that are the influence of factors outside the metacognitive awareness variable.

Keywords: metacognitive awareness, self and peer assessment, active learning, assessments, cognitive abilities

\section{INTRODUCTION}

A test and evaluation result of the Program for International Student Assessment (PISA) in 2015 shows the science performance of Indonesian students' is still low. The average achievement score of Indonesian students for science is ranked 64 out of 72 countries evaluated (OECD, 2016). The rating and average score of Indonesian students is slightly 
increased from the previous PISA test and evaluation results in 2012 at 71, but still in the low material mastery category (OECD, 2012). The science performance of Indonesian students in low category is certainly a problem that solutions must seek.

The success of students in completing science tasks can depend on their awareness of what is known and how to apply it or metacognition activities (Lai, 2011; Wilson \& Bai, 2010). One's metacognition activities are unique and difficult to measure (Akturk \& Sahin, 2011; Williams \& Atkins, 2009). It is therefore necessary to make an assessment that allows the individual to know about himself in order to determine his way of thinking and how to do something.

Metacognitive awareness of Indonesian students' is still low (Pantiwati, 2012). Therefore, through self-assessment is expected to increase students' metacognitive awareness. According to Millis (2016), a good metacognitive awareness will encourage students to learn to be better.

Science Course is one of many courses intended to encourage students to deeply implement Science precisely (Ball \& McDiarmid, 1990; Feiman-Nemser, 2001). In common, students find it difficult to apprehend and put Science into practice precisely (Çimer, 2012; Haase, 2009; Shandomo \& Zalewski, 2008). This is likely affected by the fact that students have not fully comprehended the essential concept of Science well. In essence, Science is to be comprehensively apprehended considering the fact that Science is said to be a foundation for Science instruction, holistically as well as contextually (Cobern, 1993; Liakopoulou, 2011).

Students are not only required to comprehend the essence of Science, but also to be able to skillfully manage laboratories, select instructional strategies, and prepare for wellstructured instructional activities based on the desired goals as well (Callahan et al., 2009; Hofstein \& Lunetta, 2003). Students, projected to be prospective teachers, in addition to being able to comprehend the concept, are also supposed to have a good thinking skills (Husamah \& Pantiwati, 2014) and metacognitive awareness (Abdellah, 2015; Cihanoglu, 2012; Demirel, 2015; Husamah, 2015). Metacognitive awareness is also a part of skill of thinking that is to be kept being maintained as well as developed (Fisher, 1998; Lai, 2011). Some efforts are to be formulated in order to improve metacognition; one of which can be through a training session during lecturing process integrated with instructional activities (Gassner, 2009; Shen \& Liu, 2011). The integration technique, furthermore, is employed by means of active learning by implementing a skill training assisted by cooperative learning or other relevant techniques that still adopt the main principles of active learning (Jayapraba, 2013; Wirth $\&$ Perkins, 2008).

Active learning constitutes any kinds of instructional activities that allow the students to actively participate during the instructional process, which can be in the form of interaction among students or interaction between students and lecturers during any instructional activities (Bell \& Kahrhoff, 2006; Prince, 2004). Students are supposed to be easier to identify who they are when they are directed and facilitated so as to accelerate the improvement of their metacognitive awareness (Garrison, 2011; Tavakoli, 
2014). Considering active learning through the employment of various strategies, methods, and techniques, it is believed that active learning can activate instructors and learners to arrive at effective learning. Every learning component actively contributes to support instructional activities as that of assessment components that have been part of active learning (Gibson \& Shaw, 2010; Jones, 2005). The high-quality learning itself can be reflected by the high-quality and effective assessments (Conley \& DarlingHammond, 2013; Darling-Hammond et al., 2013).

One foremost principle in assessment is that assessment and teaching can be one and the same (O'Farrell, 2009; Spiller, 2009); in which, by means of authentic and assessmentbased class, students and instructors are to view their instruction and its supporting components as a real and developing learning ambience (Stiggins, 2006). Henceforth, it is of necessity to find out other forms of assessment that can cover lecturers' weaknesses (Widiyowati \& Usmanti, 2013). In response to that case, lecturers are allowed to collaborate with their students in terms of the usage of peer and self-assessments. By means of these kinds of assessment, students are also supposed to learn based on the used assessment process. Students are to learn and be helped during instructional activities (Popham, 2006; Popham, 2007; Popham, 2008). Peer assessment can be used to assist self-assessment. Self-assessment, henceforward, is supposed to support students to be more responsible for their improved learning performance (Nirwana, 2013).

Classroom assessment can be projected to detect some cognitive abilities, metacognition, and concept fallacy (Schraw et al., 1998). Students, whose metacognition is high and who have critical thinking and are well-creative, will be at ease to learn and understand various concepts or materials expansively. A classroom action research on the self-assessment as the learning strategy shows that self-assessment can help the students monitor their own improvement, motivate the students to perform well during the instruction, and give the students the chance for the feedbacks (Pantiwati, 2011; Pantiwati, 2013; Pantiwati, 2015).

The implementation of self-assessment refers to three main dimensions. The first is that self-assessment has been deemed to influence the positive attitude and perception on instructional activities. The second is that self-assessment is potential to broaden students' knowledge despite the requirement of self-evaluation on what they have learnt. Meanwhile, in analyzing, the excellent way of thinking is of urgency in order to be able to think critically as well as to analyze what they have learnt; that later it is called metacognition. Students must not only be able to improve their understanding skill, but also their analysis, synthesis, evaluation, and metacognition skills (Wing Jan \& Wilson, 1998).

On the other hands, peer-assessment that has been initiated and implemented in a very good way has been said to improve learners' cognition, logic, and communication skills (Rochmiyati, 2013). Peer-assessment can drive students to evaluate their working performance compared to their friends' working performance. Evaluation refers to the highly-excellent way of thinking which also requires students to evaluate other students' performance so they could do a reflection and make it their learning experience (de Raadt et al., 2005). 
Departing from that reason, through the self and peer-assessments, students also develop their metacognition skill as well as their cognitive abilities, to be specific the way how to formulate a highly-excellent way of thinking as being asserted in the Revision of Bloom Taxonomy started from aspect $\mathrm{C} 4, \mathrm{C} 5$, and C6 that include analysis, evaluation synthesis, and even creativity. Self-assessment is to improve students' intrinsic motivation and learning strategies so that the learning outcome will be highly satisfying. Self-assessment, essentially, constitutes an authentic assessment that facilitates the improvement of learning quality to mainly improve students' learning outcomes (Pantiwati, 2011; Pantiwati, 2015). Moreover, this research integrated self and peerassessments in active learning with the aims of investigating its influence to the cognitive abilities and metacognitive awareness of the students. This research was conducted for a number of objectives, precisely to investigate: 1) the influence of self and peer-assessments in active learning to metacognitive awareness; 2) the influence of cognitive knowledge, cognitive regulation, and the combination between the two to metacognitive awareness; 3 ) the influence of cognitive knowledge, cognitive regulation, and the combination of the two to cognitive variable, and 4) the influence of metacognitive awareness to cognitive variable.

\section{METHOD}

\section{Research Concept Framework}

The framework of this research, denoting the wholeness of self-assessment in active learning model by means of various learning strategies for cognitive abilities and metacognitive awareness, is presented in Figure 1.

\section{Research Design}

This research belonged to pre-experimental research design due to the presence of external variable that influenced the formation of the dependent variables. As a consequence, the experiment result has shown that the dependent variables which refer to metacognitive awareness and cognitive abilities were not necessarily influenced by the independent variable, which was self-assessment in active learning model. This happened due to the absence of the controlling variables in addition to the fact that the samples were not randomized.

\section{Population, Sample, and Sampling Technique}

The population of this research was a group consisting of students attending Science Course in Faculty of Teacher Training and Education of University of Muhammadiyah Malang, Indonesia. The samples signified all members of the population. In addition, for the sampling technique, saturation sampling was employed since all members of the population were recruited as the samples. The sample of this study is all students in a class that take the Science Course, a number of 59 students. The reason for selecting the sample is referring to Goodwin (2012) and Sugiyono (2010) that if the population is less than 100 then it can use the saturation sample. In addition, this research wants to generalize with a very small error. 


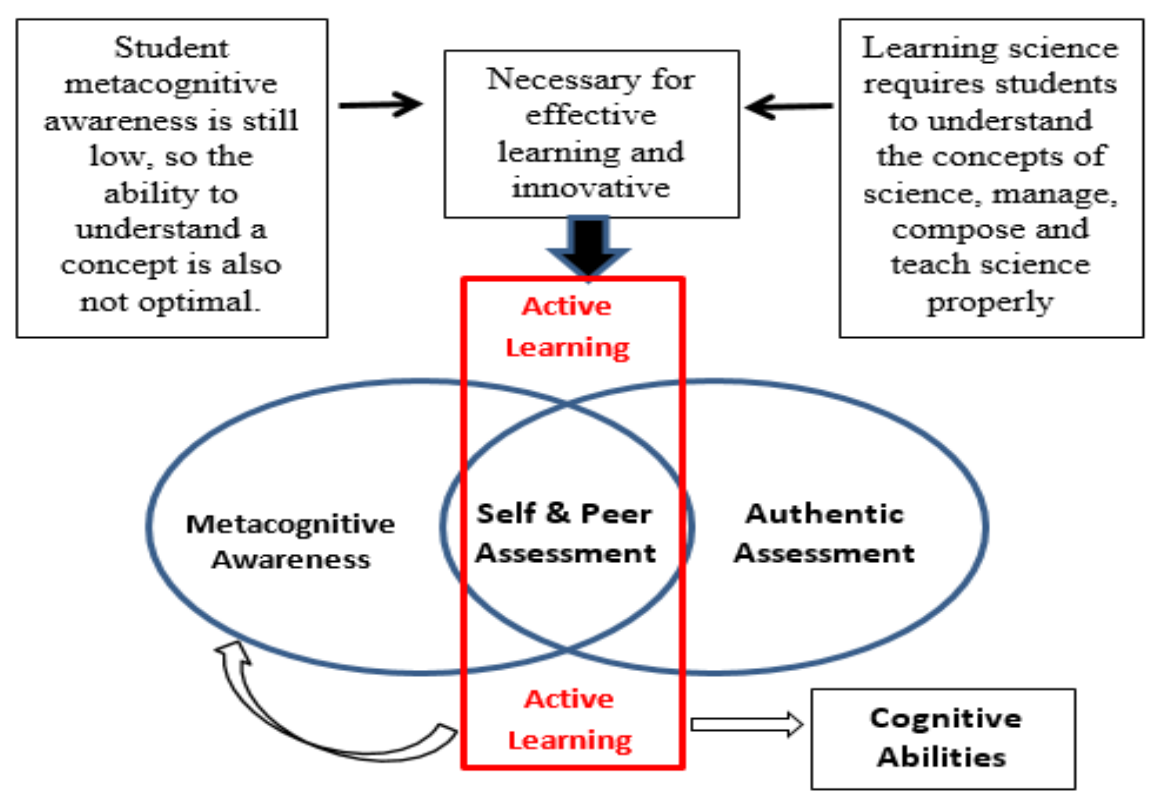

Figure 1

Research Concept Framework

\section{Teaching Variable and Syntax}

The dependent variables of this research referred to metacognitive awareness and cognitive abilities; while the independent variable referred to the integration of self and peer-assessments in active learning model of which indicators and observed aspects are displayed in Table 1.

Table 1

Teaching Variable

\begin{tabular}{|c|c|}
\hline $\begin{array}{l}\text { Teaching } \\
\text { Variable }\end{array}$ & Indicators \\
\hline Dependent & $\begin{array}{l}\text { 1. Self Assessment and Peer assessment, includes: a) presentation, b) Poster, } \\
\text { c) Log learning, d) working group, e) Problem solving f) report/essay, g) } \\
\text { Bibliography, h) practicals, and i) Portfolio } \\
\text { Active learning: a) Think-Pair-Share, b) Collaborative Learning Groups, } \\
\text { c) Student-led Review Session, d) Student Debate, e) Exam questions } \\
\text { writing, Class Research Symposium, and f) Case Studies }\end{array}$ \\
\hline Independent & $\begin{array}{l}\text { 1. Metacognitive awareness: } \\
\text { a. Cognitive knowledge (declarative; procedural; conditional knowledge) } \\
\text { b. Cognitive regulation (Planning; Information Management Strategy; } \\
\text { Monitoring of understanding; repairs; Evaluation) } \\
\text { 2. Cognitive abilities: } 6 \text { aspects of Bloom's taxonomy (knowledge, } \\
\text { comprehension, application, analysis, synthesis, evaluation) }\end{array}$ \\
\hline
\end{tabular}




\section{Methods for Data Collection and Analysis}

To collect the data, some procedures were employed based on the research objectives and types of data which are holistically displayed in Table 2.

Table 2

Method of collecting data

\begin{tabular}{llll}
\hline Data & $\begin{array}{l}\text { Source of } \\
\text { Data }\end{array}$ & $\begin{array}{l}\text { Instrument of } \\
\text { Collecting Data }\end{array}$ & $\begin{array}{l}\text { Method of collecting } \\
\text { data }\end{array}$ \\
\hline $\begin{array}{l}\text { Implementing } \\
\begin{array}{l}\text { Self and Peer } \\
\text { Assessment in } \\
\text { active learning }\end{array}\end{array}$ & $\begin{array}{l}\text { Lecturer, } \\
\text { students, } \\
\text { learning } \\
\text { situation }\end{array}$ & $\begin{array}{l}\text { Observing guide, } \\
\text { document }\end{array}$ & $\begin{array}{l}\text { Observation, document, } \\
\text { and interview }\end{array}$ \\
\hline $\begin{array}{l}\text { Metacognitive } \\
\text { awareness }\end{array}$ & Students & $\begin{array}{l}\text { Metacognitive } \\
\text { Awareness } \\
\text { Inventory of Schraw } \\
\text { \& Dennison (1994) }\end{array}$ & Inventory \\
\hline $\begin{array}{l}\text { Cognitive } \\
\text { abilities }\end{array}$ & Students & Test and non-test & $\begin{array}{l}\text { Test, observation, } \\
\text { document, interview }\end{array}$ \\
\hline
\end{tabular}

The pre-test and post-test used in this study were essays of 15 items, the total score was 100 based on Bloom's Taxonomy, ie aspects C4, C5, and C6.

\section{Path Analysis}

The path analysis diagram has revealed the connection among cognitive knowledge (x1), cognitive regulation (x2), metacognitive awareness (x3), and cognitive variable $(\mathrm{x} 4)$ as noted in Figure 2.

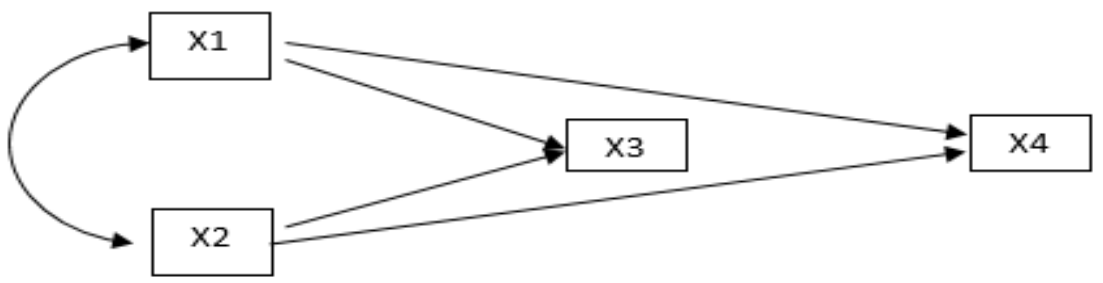

Figure 2

Path Analysis Diagram

\section{FINDINGS AND DISCUSSION}

The influence of self and peer-assessments in active learning model to metacognition and cognitive abilities was analyzed by comparing the MAI score between the pre-test and post-test. This categorization refers to Pantiwati (2010) who divides the percentage of metacognitive awareness scores by $<40.0 \%$ which means very poor; $40.0-54.9 \%$ means poor; 55.0-69.9\% means fair; 70.0-80.0 means good; and >80.0 means very good.) 
Furthermore, the analysis was conducted by calculating every score of each aspect achieved by the students. Afterwards, the result of the analysis was used to examine the students' scores that would be used to see the score percentage of the students' metacognitive awareness in the view of classical model. The data of the students' metacognitive awareness on the pre-test and post-test are displayed in Table 3.

Table 3

Data of student's metacognitive awareness score (percentage)

\begin{tabular}{llll}
\hline Metacognitive Awareness Indicator & $\begin{array}{l}\text { Pre-test } \\
\text { Score }(\%)\end{array}$ & $\begin{array}{l}\text { Post-test } \\
\text { Score }(\%)\end{array}$ & Information \\
\hline Cognitive knowledge & & & \\
$\quad$ - Declarative knowledge & 67.5 & 75.9 & Increase 8.4 \\
- Procedural knowledge & 69.5 & 77.8 & Increase 8.3 \\
- Conditional knowledge & 73.1 & 81.2 & Increase 8.1 \\
Cognitive Coordination & & & \\
- Planning & 72.7 & 79.5 & Increase 6.8 \\
- Information management Strategy & 68.8 & 78.2 & Increase 9.4 \\
- Cognitive experiences & 73.1 & 79.7 & Increase 6.6 \\
- Improvement & 75.5 & 82.5 & Increase 7.7 \\
- Evaluation & 67.2 & 77.2 & Increase 10 \\
\hline
\end{tabular}

Table 3 has shown that metacognitive awareness of the two observed indicators revealed that, on the post-test scores, the highest aspect of cognition was pre-requisite knowledge by $81.2 \%$ (meaning excellent and improving by 8.1 ), followed by procedural knowledge by $77.8 \%$ (meaning good and improving by 8.3 ), and declarative knowledge by $75.9 \%$ (meaning good and improving by 8.4 ). Meanwhile, in terms of cognitive coordination, the highest score was the aspect with $82.5 \%$ improvement (meaning good and improving by 7 ). The other indicators included cognitive experience by $79.7 \%$ (meaning good and improving by 6.6 , planning by $79.5 \%$ (meaning good and improving by 6.8), informational management strategy by $78.2 \%$ (meaning good and improving by 9.4 ), and evaluation by $77.2 \%$ (meaning good and improving by 10). This denoted that selfimplementation and assessment in active learning model were upgrading the students' metacognitive awareness.

Active learning model requires students to develop their skills, such as collaboration and reflection by means of metacognition (Husamah, 2015). Active learning model will help students to improve their skill for self-reflection as manifestation of metacognitive awareness. While referring to the last stage of active learning model, this model was also helpful in drilling students' way of thinking (Wena, 2011). Metacognitive awareness during any instructional process could be by means of various ways, categorized into several learning strategies; two of which are from students themselves, and their ways of learning (Corebima, 2009). The implementation of self and peerassessments was, empirically and theoretically, in line with the previous research that is upgrading students' metacognition (Pantiwati, 2013; Pantiwati, 2015). The summary of path analysis is displayed in the following Table 4. 
Table 4

Summary of direct, correlative, and total influence with path analysis

\begin{tabular}{llll}
\hline Design & Direct influence & Correlative influence & Total influence \\
\hline X1 to X3 & 0.088 & 0.151 & 0.239 \\
X2 to X3 & 0.429 & 0.151 & 0.580 \\
Combination influence X1 and X2 to X3 & & 0.819 \\
\hline X1 to X4 & 0.084 & 0.132 & 0.216 \\
X2 to X4 & 0.346 & 0.132 & 0.478 \\
Combination influence X1 and X2 to X4 & & 0.694 \\
\hline X3 to X4 & 0.712 & - & 0.712 \\
Correlation X1 and X2 & & & 0.778 \\
\hline
\end{tabular}

The result of the path analysis also showed that, statistically, the proposed path analysis was acceptable, with a direct influence, correlative influence, and the total of influence as explicated in Table 4. Cognitive knowledge has shown to provide the direct influence to metacognitive awareness by $8.8 \%$. Cognitive knowledge, in addition, influenced metacognitive awareness through a correlative connection with cognitive regulation (in other words giving an indirect influence) by $15.1 \%$; therefore, the total influence of cognitive knowledge to metacognitive awareness was as much as $23.9 \%$. Cognitive regulation has shown a crucial influence to metacognitive awareness by $42.9 \%$. In addition, cognitive regulation influenced metacognitive awareness by means of correlative connection with cognitive knowledge (having an indirect influence) by $15.1 \%$; therefore, the total influence of cognitive regulation to metacognitive awareness signified $58 \%$.

The influence of the combination between cognitive awareness and cognitive regulation to metacognitive awareness signified $18.1 \%$ which comprised the presence of an external factor. Revisiting the total amount of comparison between cognitive knowledge and cognitive regulation to metacognitive awareness, cognitive regulation has significantly influenced metacognitive awareness than that of cognitive knowledge.

Cognitive knowledge was shown to have a direct influence to cognitive variable by $8.4 \%$. Cognitive knowledge has influenced cognitive variable through correlative connection with cognitive regulation (been indicated as an indirect influence) by $13.2 \%$; therefore, the total influence of cognitive knowledge to cognitive variable constituted $21.6 \%$. Furthermore, cognitive regulation has shown a direct influence to cognitive variable by $34.6 \%$. The influence of cognitive regulation was identified to have been present on cognitive variable due to a correlative connection with the cognitive knowledge (asserted as an indirect influence) by $13.2 \%$. As a consequence, cognitive regulation provided cognitive variable with the total influence of $47.8 \%$.

The influence of the combination between cognitive awareness and cognitive regulation to cognitive variable signified as much as $69.4 \%$ in total which meant that there was another $30.6 \%$ constituting an external factor excluding the two mentioned variables. Comparing the total influence between cognitive knowledge and cognitive regulation, cognitive regulation has been deemed to influence cognitive variable more significantly than that of cognitive knowledge. Metacognitive awareness has directly influenced 
cognitive variable by $71.2 \%$. Therefore, it could be inferred that the other $28.8 \%$ referred to an external factor apart from metacognitive awareness.

The ability of metacognition can be enhanced through the activity of realizing and understanding declarative knowledge, procedural knowledge, and conditional knowledge. We have analyzed the students' assignments in the form of lattice questions and made observations and interviews as they worked out the tasks. The result of the analysis shows that the student has known how to arrange the test instrument that must be preceded by the activity of making the lattice questions. They also realize that the preparation of the lattice requires understanding a good concept of instrument development. This knowledge is classified in declarative knowledge, ie, factual information known to a person. According to Schiefelbein and McGinn (2017) declarative knowledge can be expressed by someone orally and through writing.

Furthermore, to do the task of preparing the grid problem, composing the instrument, test the instrument and the task of analyzing the test results the student must develop his knowledge by thinking how to find ways or strategies to finish the task. The results of the interviews and observations and analysis of student task documents show that students use various means to accomplish these tasks and vary in each group. These methods and strategies, in metacognition are classified as procedural knowledge. Procedural knowledge is the knowledge of how a person does something, the knowledge of how a person performs in carrying out the steps in a process.

Procedural understanding (comprehension) is defined as proposing questions about how science is understood through observations and what the observations are; As establishing connections between plans, hypotheses and estimations; And as searching for, collecting and interpreting data (Harlen, 2000; Harlen \& Holroyd, 1996; Traianou, 2006). Nevertheless, the study results of Yilmaz and Yalcin (2012) show that students' success rate does not reflect their level of knowledge. Students experience some problems when changing procedural knowledge into declarative knowledge, and because of this problem, students fail to "understand" the material. This is different from the findings of this study, students show the development of good thinking so that the understanding of the material to be better. Students say that through the assignment given by the lecturer, they become aware and understand about the concept of the material, even easier to understand the material because students feel to work independently and have the freedom to express so more motivated. This is in accordance with the opinion of Kompal (2015) where appears a positive relationship between motivation and metacognition as well as the associated academic achievement of students. This activity is known as the application of metacognition for conditional knowledge, ie knowledge of when a procedure, skill or strategy is used and when it is not used, under what conditions a procedure can be used, and why a procedure is better than other procedures.

This research's findings are similar to that of previous researches and literatures. Active learning is learning-learner action oriented. Learners play an active role alongside other learning components; therefore, it is not only the lecturer and students who are active, but all components as well (Hermawan, 2007). Active learning in this case is a learning 
model that has a particular characteristic, that the first concept model suggests something larger than strategies, methods, or specific techniques. This model has some attributes, namely the existence of a coherent theoretical basis of what should be learned and how students learn. This model recommends a variety of teaching behaviors and class structure needed to employ a variety of different types of learning. Second, the concept of the learning model serves as a communication tool, the use of a particular model that helps teachers achieve the intended goals (Arends, 2007).

Jacob \& Isaac (2006) assert that continuous assessment can improve students' learning outcomes quantitatively and qualitatively. Quantitatively, it increases students' scores; while qualitatively it can promote motivation, interests, and learning habits. Based on the elaboration above, the lecturer must assure that authentic learning takes place and always relates the materials and students' works to problems in everyday life. This is done in line with the goal of authentic assessment, with regard to the principles of assessment.

Innovations in education will be achieved when the principles of learning remain applied properly. Through class-based authentic assessment, teachers, students, and others can see how real learning and development occur (Shepard, 2000; Stiggins, 1994). Assessment is said to be good, provided that it can improve the teaching of authentic assessment; and good teaching can always improve students' achievement. According to Marzano (1993), assessment offers direct and indirect influences on learning. Direct assessment provides feedback for effective learning; while indirect effect is generally inclined to the influences of what is taught and what is learned.

All ratings, including self-assessment, consist of two main elements, namely: making decisions about the expected performance standards and then making judgments about the quality of performance in relation to the standards. Likewise, self-assessment should ideally involve students in both aspects (Boud, 1995). Self-assessment is a process of formative assessment for students to reflect and evaluate the quality of student assignments, assess the extent to which students reflect the objectives explicitly stated in the criteria, identify the strengths and weaknesses in student assignments, and further revise the given tasks (Andrade \& Du, 2007).

Peer and self-assessments are claimed to be good and valid when implemented in accordance with the methods and standards of assessment (Murthy, 2008). Peer and selfassessments can measure the improvements in students' performances (Triscahyaningrum \& Susilaningsih, 2014). It is possible that there are some aspects of evaluation which can be taken apart from the assessment of student learning outcomes through the transformation of student activities, as well as through the transformation of self-assessment and peer reviews themselves. In general, learning outcomes can be identified from the results of the changes documented during the learning processes through test results, as well as through non-test such as individual cognitive, affective, and psychomotor ability mapping (Hajiriah, 2014).

We must ask ourselves if we have consciously integrated metacognitive skills in teaching practice. Metacognitive skills can be enhanced with the need to have and be 
aware of three types of content knowledge: declarative, procedural, and conditional knowledge. Declarative knowledge is factual information about something; it can be oral or written. Procedural knowledge is knowledge about how to do things and how to perform the steps in any particular process. Conditional knowledge is the knowledge of when to use the procedures, skills, or strategies and when not to use it, why certain procedure works and under what conditions, and why one procedure is better than the others (Lestari, 2012).

Weinert and Kluwe (1987) suggest that metacognitive skills require special mental operations by which learners can examine, plan, organize, monitor, predict, and evaluate their own thinking processes. Self-monitoring can be regarded as a form of metacognitive skill.

Learners with metacognitive knowledge are aware of the advantages and limitations in their learning processes, meaning that when they know their mistakes, they are willing to admit that they are mistaken, and try to fix the mistakes. They are aware that metacognitive skills are more strategic and work better, making it easier for individuals to plan, assemble, and monitor their learning in effort to consequently improve their performances directly.

Metacognitive skill as a learning approach is to create awareness of how to design, monitor, and control what learners know; what is required to do and how to do it. Learning through metacognitive approach focuses on learning activities; it helps and guides learners if there are difficulties; as well as helping them develop self-concept on what to do when learning.

The results of this study are expected to be input and consideration for lecturers and department managers who organize the Science Course. They should pay attention to how to make good assessment, one of them by applying self and peer assessments. Self and peer assessments are effectively used because they can increase students' metacognitive awareness so as to enhance metacognitive aspects and student learning process will be more effective.

\section{CONCLUSION}

Based on the results and discussion, it could be concluded that: 1) there has been an influence of self and peer-assessments in active learning to metacognitive awareness and competence. 2) Cognitive knowledge has shown direct, indirect, and total influence to metacognitive awareness variable. Cognitive regulation has shown direct, indirect, and total influence to metacognitive awareness variable. There have been contributions of the combination between cognitive knowledge and cognitive regulation as well as an external factor to metacognitive awareness variable. Cognitive regulation variable has contributed a greater influence on metacognitive awareness. 3) Cognitive knowledge has shown direct, indirect, and total influence to cognitive variable. Cognitive regulation has shown direct, indirect, and total influence to cognitive variable. There have been contributions of the combination between cognitive knowledge and cognitive regulation as well as an external factor to cognitive variable. Cognitive regulation variable has contributed a greater influence on cognitive variable, than that of cognitive knowledge 
variable. 4) Metacognitive awareness variable has shown direct influence to cognitive variable; and there was the influence of other factors apart from metacognitive awareness variable.

\section{REFERENCES}

Abdellah, R. (2015). Metacognitive awareness and its relation to academic achievement and teaching performance of pre-service female teachers in Ajman University in UAE. Procedia-Social and Behavioral Sciences, 174(2015), 560-567.

Akturk, A. O., \& Sahin, I. (2011). Literature Review on Metacognition and its Measurement. Procedia Social and Behavioral Sciences, 15(2011), 3731-3736.

Arends, R. I. (2007). Learning to teach. New York: McGraw-Hill.

Ball, D. L., \& McDiarmid, G. W. (1990). The subject-matter preparation of teachers. In W. R. Houston (Ed), Handbook of research on teacher education (pp. 437-465). New York: Macmillan.

Boud, D. (1995). Enhancing learning through self-assessment. London: Kogan Page.

Callahan, P., Cannon, B., Chesick, E., Mackin, J., Mandel, S., \& Wenning, C. (2009).

The role, education, qualifications, and professional development of secondary school physics teachers. One Physics Ellipse, College Park: The American Association of Physics Teachers.

Çimer, A. (2012). What makes biology learning difficult and effective: Students' views? Educational Research and Reviews, 7(3), 61-71.

Conley, D.T., \& Darling-Hammond, L. (2013). Creating systems of assessment for deeper learning. Stanford, CA: Stanford Center for Opportunity Policy in Education.

Corebima, A. D. (2009). Metacognitive skill measurement integrated in achievement test. Proceeding Cosmed 2009.

Demirela, M., Akınb, I., \& Yacic, A. (2015). An investigation of teacher candidates' metacognitive skills. Procedia-Social and Behavioral Sciences, 174(2015), 1521-1528.

Feiman-Nemser, S. (2001). From preparation to practice: Designing a continuum to strengthen and sustain teaching. Teachers College Record, 103(6), 1013-55.

Garrison, D. R. (2011). E-learning in the 21st century: A framework for research and practice. New York: Routledge.

Gassner, L. (2009). Developing metacognitive awareness: A modified model of a PBLtutorial. Bachelor thesis, Malmo University.

Gibson, K., \& Shaw, C. M. (2010). Assessment of active learning assessment of active learning. The International Studies Encyclopedia, DOI: 10.1111/b.9781444336597. 2010.x.

Goodwin, J. (2012). SAGE Biographical Research. LA, US: SAGE Publications. 
Haase, R. (2009). Elementary teacher's attitudes towards science and the teaching of science and technology. Electronic Theses and Dissertations, pp. 245.

Hajiriah, T. L. (2014). The correlation of the results of student learning through the development of assessment peer review and self assessment on the application of the model of cooperative type numbered head together. Bioscientist, 2(2), 288-298.

Harlen, W. (2000). The teaching of science in primary schools. London: David Fulton Publishers.

Harlen, W., \& Holroyd, C. (1996). Primary teachers' understanding of concepts in science: impact on confidence and teaching. International Journal of Science Education, 19(1), 93-105.

Harvey, L., \& Anderson, J. (1996). Transfer of declarative knowledge in complex information-processing domains. Human-Computer Interaction, 11(1), 69-96.

Hermawan. (2007). Teaching and learning. Jakarta: Asdi Mahasatya.

Hofstein, A., \& Lunetta, V. N. (2003). The laboratory in science education: Foundations for the twenty-first century. Laboratory in Science Education, 28-54.

Howard, J. (2004). Metacognitive inquiry. School of Education, Elon University.

Husamah \& Pantiwati, Y. (2014). Cooperative learning STAD-PjBL: Motivation, thinking skills, and learning outcomes in biology students. International Journal of Education Learning and Development, 2(1), 77-94.

Husamah. (2015). Blended project based learning: Metacognitive awareness of Biology education new students. Journal of Education and Learning, 9(4), 274-281.

Jacob, S. M., \& Issac, B. (2006). Observation of assessment effects and student perceptions in higher education. Proceedings of the International Conference on Measurement and Evaluation in Education III (ICMEE III), February 2006, Penang, Malaysia.

Jayapraba, G. (2013). Metacognitive instruction and cooperative learning- strategies for promoting insightful learning in science. International Journal on New Trends in Education and Their Implications, 4(1), 165-172.

Kompal, W. (2015). Metacognition and motivation: In context with the academic success of students. International Journal of Multidisciplinary Research and Development, 2(12), 66-68.

Lai, E. R. (2011). Metacognition: A literature review. Pearson Research Reports. (http://www.pearsonassessments.com, downloaded: October 2016).

Lestari, Y. D. (2012). Metakognisi siswa dalam memecahkan masalah matematika berdasarkan gaya kognitif refleksif dan impulsif. Surabaya, Indonesia: UNESA. 
Liakopoulou, M. (2011). The professional competence of teachers: Which qualities, attitudes, skills and knowledge contribute to a teacher's effectiveness? International Journal of Humanities and Social Science, 1(21), 66-78.

Marzano, R. J. (1993). Designing a new taxonomy of educational objectives. Thousand Oaks, CA: Corwin Press.

Millis, B. J. (2016). Using metacognition to promote learning. IDEA Paper \#63: December 2016.

Murthy, S. (2008). Peer-assessment of homework using rubrics. Mass. Ave., Cambridge: Massachusetts Institute of Technology.

Nirwana, R. R. (2013). Peer and self assessment as an authentic assessment in curriculum 2013. Jurnal Pendidikan MIPA, 3(2), 139-150.

O'Farrell, C. (2009). Enhancing student learning through assessment: A toolkit Approach. downloaded: October 2016, https://www.learningandteaching.dit.ie/documents/assessment_toolkit_v41f.pdf

OECD (Organisation for Economic Co-operation and Development). (2013). Country Note - Results from PISA 2012. downloaded: October 2016, https://www.oecd.org/pisa/keyfindings/pisa-2012-results-overview.pdf .

OECD (Organisation for Economic Co-operation and Development). (2016). Country Note - Results from PISA 2015. (https://www.oecd.org/pisa/PISA-2015-Indonesia.pdf, downloaded: October 2016).

Pantiwati, Y. (2010). Pengaruh jenis asesmen biologi dalam pembelajaran kooperatif TPS (Think Pair Share) terhadap kemampuan kognitif, berpikir kritis, berpikir kreatif, dan kesadaran metakognitif siswa SMA di kota Malang. Unpublished Dissertation. Malang: Program Pascasarjana UM. (In Indonesian).

Pantiwati, Y. (2011). Authentic assessment in integration of learning. DP, 11(2), 77-84.

Pantiwati, Y. (2012). Influence of biological assessment in think pair share learning against the cognitive ability of students. Jurnal Ilmu Pendidikan, 18(2), 236-243.

Pantiwati, Y. (2013). Authentic assessment for improving cognitive skill, criticalcreative thinking and meta-cognitive awareness. Journal of Education and Practice, 4(14), 1-9.

Pantiwati, Y. (2015). Learning strategies, self assessment, and Metacognition in learning science. Proceedings of the National Seminar on Education Biology 2015.

Popham, W. J. (2007). Instructional sensitivity: Educational accountability's dire deficit. Phi Delta Kappan, 89(2), 149-155.

Popham, W. J. (2008). Transformative assessment. Alexandria, VA: Association for Supervision and Curriculum Development. 
Preisseisen, B. (1985). Unlearning Lessons: Current and Past Reforms for School Improvement. Philadelphia: Falmer Press.

Prince, M. (2004). Does Active Learning Work? A Review of the Research. Journal of Engineering Education, 93(3), 223-231.

Rochmiyati. (2013). Peer assessment model on collaborative elaboration learning for interdisciplinary social studies in the junior high schools. Jurnal Penelitian dan Evaluasi Pendidikan, 17(2), 333-346.

Schiefelbein, E., \& McGinn, N. F. (2017). Learning to educate: Proposals for the reconstruction of education in developing countries. Rotterdam, the Netherlands: Sense Publishers.

Schraw, G., \& Dennison, R. S. (1994). Assessing metacognitive awareness. Contemporary Educational Psychology, 19, 460-475.

Schraw, G., Flowerday, T., \& Reisetter, M. F. (1998). The role of choice in reader engagement. Journal of Educational Psychology, 90, 705-714.

Shen, C. Y., \& Liu, H. C. (2011). Metacognitive skills development: A web-based approach in higher education. TOJET: The Turkish Online Journal of Educational Technology, 10(2), 140-150.

Shepard, L. A. (2000). The role of classroom assessment in teaching and learning. Los Angeles Los Angeles, CA: Graduate School of Education \& Information Studies University of California.

Spiller, D. (2009). Assessment: Feedback to promote student learning. New Zealand: Teaching Development Unit, The University of Waikato.

Stiggins, R. J. (2006). Assessment for learning: A key to student motivation and learning. Phi Delta Kappa Edge, 2(2), 1-19.

Sugiyono. (2010). Metode penelitian kuantitatif-kualitatif dan $R \& D$. (The method of quantitative-ualitative research and $R \& D$. Bandung: Alfabeta. (In Indonesian Language).

Tavakoli, H. (2014). The effectiveness of metacognitive strategy awareness in reading comprehension: The case of Iranian university EFL students. The Reading Matrix, 14(2), 314-336.

Traianou, A. (2006). Teachers' adequacy of subject knowledge in primary science: assessing constructivist approaches from a socio cultural perspective. International Journal of Science Education, 28(8), 827-842.

Triscahyaningrum, T., \& Susilaningsih, E. (2014). Implementation of peer and self assessment on learning strategies of chemistry lectures. Chemistry in Education, 2(3), 192-199. 
Walser, T. M. (2009). An action research study of student self-assessment in higher education. Innovative Higher Education, 2009(34), 299.

Weinert, F. E., \& Kluwe R. H. (Ed). (1987). Metacognition, motivation, and understanding. Hillsdale, N.J.: Erlbaum.

Wena, M. (2011). Contemporary innovative learning strategies (a conceptual review of operations). Jakarta: Bumi Aksara.

Widiyowati, I. I., \& Usmanti, F. (2013). The implementation analysis of self assessment to assess the student of xi senior high school performance in chemistry equilibrium practicum. Proceedings of the National Seminar on chemistry of 2013.

Williams, J. P., \& Atkins, J. G. (2009). The role of metacognition in teaching reading comprehension to primary students. In Hacker, D. J., Dunlosky, J., \& Graesser, A. C. (Ed), Handbook of metacognition in education (pp. 26-43). New York, NY: Routledge.

Wilson, N. S., \& Bai, H. (2010). The relationships and impact of teachers' metacognitive knowledge and pedagogical understandings of metacognition. Metacognition Learning. DOI 10.1007/s11409-010-9062-4.

Wing Jan, L., \& Wilson, J. (1998). Integrated assessment. Oxford, UK: Oxford University Press.

Wirth, K. R., \& Perkins, D. (2008). Learning to learn. downloaded: October 2016, http://www.macalester.edu/geology/wirth/CourseMaterials.html

Yilmaz, I., \& Yalcin, N. (2012). The relationship of procedural and declarative knowledge of science teacher candidates in newton's laws of motion to understanding. American International Journal of Contemporary Research, 2(3), 50-56.

\section{Turkish Abstract}

Bilişsel Bilinci ve Bilişsel Yetenekleri Artırmak İçin Aktif Öğrenme Modelinde Benlik ve Akran Değerlendirmesi

Bu çalışma, 1) aktif öğrenme modelinde benlik ve akran değerlendirmelerinin bilişsel farkındalık ve bilişsel yeteneklere etkisini; 2) bilişssel bilginin, bilişsel düzenlemenin ve bilişsel bilgi ile bilişsel düzenleme arasındaki kombinasyonun bilişsel farkındalığa katkısını; 3) Bilişsel bilginin, bilişsel düzenlemenin ve bilişsel bilgi ile bilişsel düzenleme arasındaki kombinasyonun bilişsel değişime katkısını; ve 4) Bilişsel farkındalığın bilişsel değişkene katkısını araştırmayı amaçlamıştır. Araştırma sonunda: 1) Metabiliş bilinci ve bilişsel yeteneğin farkında olunmasına yönelik aktif öğrenmede kendilik ve akran değerlendirmesinin etkilerinin olduğu; 2) Bilişsel bilgi, bilişsel düzenlemeler ve birleşik iki başlık da Üstbiliş farkındalığına etkisini arttırdığ 1 bulunmuştur.

Anahtar Kelimeler: bilişsel farkındalık, benlik ve akran eğerlendirmesi, aktif öğrenme, değerlendirme, bilişsel farkındalık, bilişsel beceriler 


\section{French Abstract}

\section{Soi et Pair Évaluations dans Modèle d'Apprentissage Actif pour Augmenter Conscience} Metacognitive et Capacités Cognitives

Cette recherche visant à examen: 1) l'influence de soi et évaluations de pair dans modèle d'apprentissage actif à conscience metacognitive et capacités cognitives; 2) la contribution de connaissance cognitive, règlement cognitif et la combinaison entre connaissance cognitive et règlement cognitif à conscience metacognitive; 3) la contribution de connaissance cognitive, règlement cognitif et la combinaison entre connaissance cognitive et règlement cognitif à variable cognitive; et 4) la contribution de conscience metacognitive à variable cognitive. L'analyse de chemin de résultat a montré: 1) Il y a les influences de soi et l'évaluation de pair dans l'apprentissage actif vers la conscience de Metacognition et la capacité cognitive; 2) la connaissance cognitive, le règlement de cognitifs et combiné tous les deux ont contribué à son influence sur la conscience Metacognition.

Mots Clés: metacognitive conscience, soi et pair(égal) évaluation, apprentissage actif, évaluations, metacognitive conscience, capacités cognitives

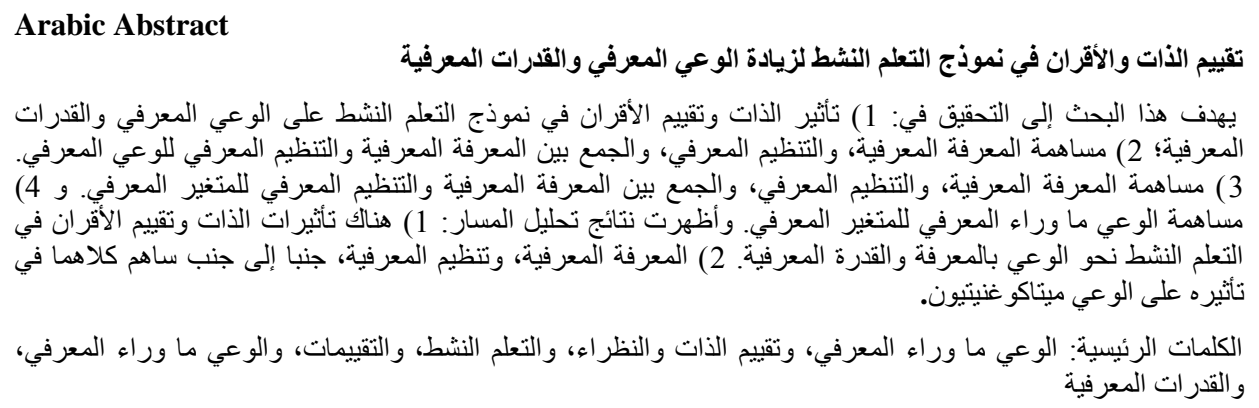

\section{German Abstract \\ Self and Peer Assessments in Active Learning Model to Increase Metacognitive Awareness and Cognitive Abilities}

Diese Forschung zielte darauf ab, 1) den Einfluss von Selbst- und Peer-Assessments im aktiven Lernmodell auf metakognitives Bewusstsein und kognitive Fähigkeiten zu untersuchen; 2) der Beitrag des kognitiven Wissens, der kognitiven Regulierung und der Kombination zwischen kognitivem Wissen und kognitiver Regulierung zum metakognitiven Bewusstsein; 3) der Beitrag des kognitiven Wissens, der kognitiven Regulierung und der Kombination zwischen kognitiver Erkenntnis und kognitiver Regulierung zur kognitiven Variablen; und 4) der Beitrag des metakognitiven Bewusstseins zur kognitiven Variablen. Die Ergebnispfadanalyse zeigte: 1) Es gibt Einflüsse von Selbst- und Peer-Assessment im aktiven Lernen zum Bewusstsein der Metakognition und kognitiven Fähigkeiten; 2) kognitives Wissen, Regulierung der kognitiven und kombinierten beides trug zu seinem Einfluss auf Metakognition Bewusstsein.

Schlüsselwörter: metakognitives bewusstsein, selbst- und peer-bewertung, aktives lernen, einschätzungen, metakognitives bewusstsein, kognitive fähigkeiten 


\section{Malaysian Abstract \\ Penilaian Kendiri dan Rakan Sebaya dalam Model Pembelajaran Aktif untuk Meningkatkan Kesedaran Metakognitif dan Kemampuan Kognitif}

Kajian ini bertujuan untuk menyiasat: 1) pengaruh penilaian diri dan rakan sebaya dalam model pembelajaran aktif kepada kesedaran metakognitif dan kebolehan kognitif; 2) sumbangan pengetahuan kognitif, peraturan kognitif, dan gabungan antara pengetahuan kognitif dan peraturan kognitif kepada kesadaran metakognitif; 3) sumbangan pengetahuan kognitif, peraturan kognitif, dan gabungan antara pengetahuan kognitif dan peraturan kognitif kepada pemboleh ubah kognitif; dan 4) sumbangan kesedaran metakognitif kepada pembolehubah kognitif. Analisis jalur keputusan menunjukkan: 1) terdapat pengaruh penilaian diri dan rakan sebaya dalam pembelajaran aktif terhadap kesadaran metakognitif dan kemampuan kognitif; 2) pengetahuan kognitif, peraturan kognitif, dan gabungan kedua-duanya menyumbang kepada pengaruhnya terhadap kesedaran metakognitif.

Kata Kunci: kesedaran metakognitif, penilaian diri dan rakan sebaya, pembelajaran aktif, penilaian, kesedaran metakognitif, kebolehan kognitif

\section{Russian Abstract \\ Самооценка и Оценка Сверстников в Модели Активного Обучения для Повышения Метакогнитивной Осведомленности и Познавательных Способностей}

Это исследование направлено на изучение: 1) влияние самоидентификации и оценки сверстников в модели активного обучения на метакогнитивную осведомленность и познавательные способности; 2) вклад познавательных знаний, когнитивной регуляции и сочетание познавательных знаний и когнитивного регулирования с метакогнитивной осведомленностью; 3) вклад когнитивных знаний, когнитивной регуляции и сочетание познавательных знаний и когнитивной регуляции с когнитивной переменной; 4) вклад метакогнитивной осведомленности в когнитивную переменную. Анализ пути результата показал: 1) есть влияние самооценки и оценки сверстников в активном обучении осознанию метапознания и познавательной способности; 2) познавательные знания, регулирование познавательных и комбинированных, способствовали его влиянию на понимание метаконцепций.

Ключевые Слова: метакогнитивная осведомленность, оценка личности и сверстников, активное обучение, оценки, познавательные способности 